\title{
Rates of particle size reduction and passage are faster for legume compared with cool-season grass, resulting in lower rumen fill and less effective fiber
}

\author{
K. L. Kammes and M. S. Allen ${ }^{1}$ \\ Department of Animal Science, Michigan State University, East Lansing 48824-1225
}

\begin{abstract}
Effects of forage family on rates of particle size reduction in, and passage from, the rumen and the relationship of these effects with preliminary dry matter intake (pDMI) were evaluated using 13 ruminally and duodenally cannulated Holstein cows in a crossover design with a 14-d preliminary period and two 18-d treatment periods. During the preliminary period, pDMI of individual cows ranged from 19.6 to $29.5 \mathrm{~kg} / \mathrm{d}$ (mean $=25.9 \mathrm{~kg} / \mathrm{d}$ ). Experimental treatments were diets containing either a) alfalfa silage (AL) or b) orchardgrass silage $(\mathrm{OG})$ as the sole forage. Silages were chopped to $10-\mathrm{mm}$ theoretical length of cut and contained 42.3 and $58.2 \%$ neutral detergent fiber (NDF) for alfalfa and orchardgrass, respectively. Both diets contained approximately $25 \%$ forage NDF and $30 \%$ total NDF. Feed, orts, rumen, and duodenal samples were wet sieved to fractionate particles above (large) and below (small) $2.36 \mathrm{~mm}$. Indigestible NDF (iNDF) was used as a flow marker. Preliminary DMI, an index of nutrient demand, was determined during the last $4 \mathrm{~d}$ of the preliminary period when cows were fed a common diet and used as a covariate. Main effects of forage family and their interaction with pDMI were tested by ANOVA. Approximately $75 \%$ of the NDF consumed was large and $25 \%$ was small for both treatments, but cows fed AL consumed more iNDF and less potentially digestible NDF (pdNDF) than cows fed OG. The AL diet increased the reduction rate (large to small) compared with $\mathrm{OG}$ despite less rumination per unit of forage $\mathrm{NDF}$ for $\mathrm{AL}$ than $\mathrm{OG}$, suggesting alfalfa $\mathrm{NDF}$ was more fragile than orchardgrass NDF. Over $55 \%$ of particles in the rumen were below $2.36 \mathrm{~mm}$ for $\mathrm{AL}$ and OG, indicating that particle size was not a limiting constraint to passage. Passage rates $\left(k_{p}\right)$ of large iNDF and large pdNDF were similar for AL and OG, but AL increased $k_{p}$ of large pdNDF and OG decreased it as pDMI increased. The AL diet increased $k_{p}$ of small
\end{abstract}

Received October 5, 2011.

Accepted January 17, 2012.

${ }^{1}$ Corresponding author: allenm@msu.edu
iNDF and small pdNDF compared with OG, resulting in lower rumen fill for AL than OG. The $k_{p}$ of small iNDF and small pdNDF were similar within forage family, suggesting buoyancy was not limiting passage. The OG diet increased rumen pool size of large NDF compared with $\mathrm{AL}$, which likely retained small NDF, contributing to the slower $\mathrm{k}_{\mathrm{p}}$ of small iNDF and small pdNDF observed for OG. Particle size reduction was a prerequisite to ruminal passage but not a constraint. Selective retention of small particles was less for alfalfa than orchardgrass, resulting in lower rumen fill and less effective fiber.

Key words: particle size reduction, passage kinetics, selective retention, rumen pool

\section{INTRODUCTION}

Passage of digesta from the rumen is a complicated, dynamic process and is inversely related to the extent of digestion within the rumen. It involves the selective retention of undigested fiber, which allows ruminants to increase ruminal fiber digestion (Allen and Mertens, 1988) but extended ruminal retention times of the retained fiber can decrease DMI from ruminal distention (Allen, 1996). Most models used to predict feed intake and digestion do not include selective retention because it is not fully understood and difficult to measure. This implies that all particles have equal probability of escape from the rumen. However, escapable (i.e., small) and nonescapable (i.e., large) particles have different passage rates (Allen and Mertens, 1988; Voelker Linton and Allen, 2008). Additionally, heterogeneous feed fractions such as NDF, which includes indigestible NDF (iNDF) and potentially digestible NDF (pdNDF), have different ruminal kinetics (Stensig and Robinson, 1997).

Several factors contribute to the decreased probability of escape of digesta from the rumen. Particle size influences passage from the rumen but is not always a constraint because a large proportion of the particles retained in the rumen are smaller than the maximum particle size in the feces (Allen, 1996). Furthermore, particle density and buoyancy (Jung and Allen, 1995) and sequestration of small particles within the fibrous 
rumen mat (Sutherland, 1988) affect passage of particles from the rumen. Passage rate of fibrous particles depends on the reduction of particle size and the increase in particle specific gravity to permit particles to escape the rumen mat, sink to the ventral rumen, and exit the rumen via the reticular-omasal orifice (Sutherland, 1988).

Digesta passage from the rumen is affected by numerous feed and animal factors. Legumes and grasses have different ruminal kinetic parameters (Voelker Linton and Allen, 2008; Bayat et al., 2010; Krizsan et al. 2010) and increases in DMI result in a decrease in the percentage of small particles in the rumen (Okine and Mathison, 1991). Therefore, the effects of forage family and level of feed intake on ruminal passage rates are of interest in this study. Alfalfa (Medicago sativa) and orchardgrass (Dactylis glomerata L.) were selected as a representative legume and cool-season grass, respectively, and the use of preliminary DMI (pDMI), an index of nutrient demand, allowed the evaluation of treatments on animal responses in relation to level of intake and provided an indicator to test effects of intake level independent of treatments. Additionally, ruminal passage rates of individual digesta fractions, instead of entire feeds, were measured using ruminally and duodenally cannulated cows and the pool and flux method (Robinson et al., 1987).

We hypothesized that rates of particle size reduction in, and particle passage from, the rumen are faster for legumes than grasses and the rate of particle passage from the rumen increases for legumes and grasses as DMI increases. The objective of this experiment was to evaluate the relationships between voluntary DMI and effects of forage family on rates of particle size reduction in, and particle passage from, the rumen. This was accomplished using a model that fractionated the pool of NDF in the rumen into iNDF and pdNDF as well as large and small particle size pools. The rate of reduction for iNDF from large particles to small particles and individual rates of passage for each of the 4 fractions were calculated.

\section{MATERIALS AND METHODS}

This article is the second of a set of 2 from one experiment that evaluated the effects of forage family and its interaction with level of feed intake (nutrient demand). This article focuses on rates of particle size breakdown in, and particle passage from, the rumen. The companion article discusses the effect of $\mathrm{pDMI}$ on responses to treatment for production, rumen parameters, digestion kinetics, and chewing activity (Kammes and Allen, 2012).

\section{Cows and Treatments}

Experimental procedures were approved by the Institutional Animal Care and Use Committee at Michigan State University (East Lansing). Thirteen multiparous Holstein cows from the Michigan State University Dairy Cattle Teaching and Research Center were assigned randomly to treatment sequence in a crossover design experiment with one 14-d preliminary period and two 18-d experimental periods. The first $10 \mathrm{~d}$ of each period were allowed for diet adaptation and samples were collected during the final $4 \mathrm{~d}$ of the preliminary period and $8 \mathrm{~d}$ of each experimental period. Cows were 157 \pm 90 (mean \pm SD) DIM at the end of the preliminary period and were selected to provide a wide range and uniform distribution of pDMI and milk yield. During the final $4 \mathrm{~d}$ of the 14-d preliminary period, the average pDMI among cows ranged from 19.6 to $29.5 \mathrm{~kg} / \mathrm{d}$ $($ mean $=25.9 \mathrm{~kg} / \mathrm{d}$ ) and $3.5 \%$ FCM yield ranged from 24.3 to $60.3 \mathrm{~kg} / \mathrm{d}($ mean $=42.1 \mathrm{~kg} / \mathrm{d}$; Table 1$)$. Prior to calving, cows were cannulated ruminally (Bar Diamond Inc., Parma, ID) and duodenally with a gutter-type $\mathrm{T}$ cannula placed approximately $10 \mathrm{~cm}$ distal to the pylorus (Joy et al., 1997). Surgery was performed at the Department of Large Animal Clinical Science, College of Veterinary Medicine, Michigan State University.

Experimental treatments were diets containing either a) alfalfa silage (AL) or b) orchardgrass silage ( $\mathbf{O G}$ ) as the sole forage. Details regarding forages at time of harvest were described by Kammes and Allen (2012).

Table 1. Characterization of 13 cows during the final $4 \mathrm{~d}$ of the 14-d preliminary period, when cows were fed a common diet

\begin{tabular}{lccccc}
\hline Parameter & Median & Mean & SD & Minimum & Maximum \\
\hline Parity & 3 & 3.31 & 1.16 & 2 & 5 \\
BW, ${ }^{1} \mathrm{~kg}$ & 591 & 587 & 51 & 489 & 710 \\
BCS & 2.00 & 2.35 & 0.69 & 1.58 & 4.00 \\
DIM & 132 & 157 & 90 & 64 & 337 \\
Milk, kg/d & 41.4 & 41.5 & 10.8 & 22.6 & 57.1 \\
$3.5 \%$ FCM, kg/d & 43.1 & 42.1 & 11.9 & 24.3 & 60.3 \\
DMI, kg/d & 26.7 & 25.9 & 3.0 & 19.6 & 29.5 \\
\hline
\end{tabular}

${ }^{1}$ Empty BW (ruminal digesta removed). 
Table 2. Chemical composition and particle size distribution of the alfalfa silage and orchardgrass silage included in the treatment diets

\begin{tabular}{|c|c|c|}
\hline \multirow[b]{2}{*}{ Item } & \multicolumn{2}{|c|}{ Silage } \\
\hline & Alfalfa & Orchardgrass \\
\hline \multicolumn{3}{|l|}{ Chemical composition } \\
\hline DM, \% & 43.5 & 33.7 \\
\hline $\mathrm{OM}, \% \mathrm{DM}$ & 91.9 & 90.3 \\
\hline $\mathrm{NDF}, \% \mathrm{DM}$ & 42.3 & 58.2 \\
\hline $\mathrm{iNDF},{ }^{1} \% \mathrm{DM}$ & 23.0 & 16.1 \\
\hline iNDF, $\%$ of NDF & 54.5 & 27.7 \\
\hline $\mathrm{ADF}, \%$ of $\mathrm{DM}$ & 35.0 & 36.4 \\
\hline $\mathrm{ADL}, \%$ of $\mathrm{DM}$ & 7.56 & 6.03 \\
\hline $\mathrm{CP}, \% \mathrm{DM}$ & 22.5 & 11.4 \\
\hline Starch, \% DM & 1.87 & 1.37 \\
\hline NDF digestibility, ${ }^{2} \% / \mathrm{h}$ & 38.3 & 53.3 \\
\hline \multicolumn{3}{|l|}{ Particle size distribution $^{3}$} \\
\hline \multicolumn{3}{|l|}{ Wet sieving, \% DM retained } \\
\hline $19.0 \mathrm{~mm}$ & 21.4 & 12.3 \\
\hline $9.50 \mathrm{~mm}$ & 18.0 & 18.4 \\
\hline $4.75 \mathrm{~mm}$ & 30.8 & 37.2 \\
\hline $2.36 \mathrm{~mm}$ & 17.0 & 21.2 \\
\hline $1.18 \mathrm{~mm}$ & 5.72 & 6.15 \\
\hline $0.600 \mathrm{~mm}$ & 3.09 & 2.08 \\
\hline $0.300 \mathrm{~mm}$ & 1.97 & 1.02 \\
\hline $0.150 \mathrm{~mm}$ & 1.16 & 0.94 \\
\hline $0.075 \mathrm{~mm}$ & 0.40 & 0.37 \\
\hline $0.038 \mathrm{~mm}$ & 0.50 & 0.37 \\
\hline Mean particle size,${ }^{4} \mathrm{~mm}$ & 11.6 & 9.66 \\
\hline \multicolumn{3}{|c|}{ Penn State Particle Separator, \% DM retained } \\
\hline$>19.0 \mathrm{~mm}$ & 29.3 & 17.1 \\
\hline 19.0 to $8.0 \mathrm{~mm}$ & 48.5 & 50.2 \\
\hline$<8.0 \mathrm{~mm}$ & 22.2 & 32.7 \\
\hline
\end{tabular}

Briefly, alfalfa (Pioneer 54H91; Pioneer Hi-Bred International Inc., Johnston, IA) and orchardgrass (Baridana cultivar; Barenbrug USA, Tangent, OR) were produced at the campus farm at Michigan State University (East Lansing), chopped to 10-mm theoretical length of cut, and ensiled in Ag-Bags (Ag-Bag Systems Inc., St. Nazianz, WI). During the sample collection periods, alfalfa and orchardgrass contained 42.3 and $58.2 \% \mathrm{NDF}$ and 22.5 and $11.4 \% \mathrm{CP}$, respectively (DM basis; Table 2). Diets AL and OG were formulated to contain $25 \%$ forage NDF, $30 \%$ total NDF, and $18 \%$ $\mathrm{CP}$. The diet fed during the preliminary period was formulated so that alfalfa and orchardgrass each contributed $50 \%$ of forage NDF. Diets also contained dry ground corn, SoyPLUS (West Central Soy Cooperative, Ralston, IA), and vitamin-mineral premix (Table 3); soybean meal ( $48 \% \mathrm{CP})$, urea, and limestone were used to compensate for lower $\mathrm{CP}$ and $\mathrm{Ca}$ concentrations in orchardgrass silage than in alfalfa silage. We acknowledge these treatments affect the quality of dietary $\mathrm{CP}$ and starch concentration, but maintaining similar forage and total NDF concentrations for both treatments was of primary interest. Although small differences in nonforage NDF concentration were unavoidable, we recognize the sources of nonforage NDF used consisted of small particles.

\section{Data and Sample Collection}

Throughout the experiment, cows were housed in tiestalls, milked in a parlor twice daily (0400 and 1430 $\mathrm{h})$, and fed diets as TMR once daily (1130 h) at $110 \%$ of expected intake. The amount of feed offered and refused (orts) was weighed daily for each cow. Forage samples were collected twice weekly and analyzed to adjust diets to account for DM, NDF, and CP fluctuation. Samples of all dietary ingredients and TMR (0.5 $\mathrm{kg}$ ) and orts (12.5\%) were collected daily from d 11 to 14 during the preliminary period and d 11 to 15 during each experimental period. Samples were frozen immediately after collection at $-20^{\circ} \mathrm{C}$ and combined into 1 composite sample per period before analysis.

Duodenal samples $(900 \mathrm{~mL})$ were collected every 15 $\mathrm{h}$ from d 11 to 15 of each experimental period so that 8 
Table 3. Ingredients and chemical composition of preliminary and treatment diets (as analyzed) containing either alfalfa $(\mathrm{AL})$ or orchardgrass $(\mathrm{OG})$ silage as the sole source of forage

\begin{tabular}{lccc}
\hline Composition & Preliminary & AL & OG \\
\hline Ingredient, \% DM & & & - \\
Alfalfa silage & 30.0 & 59.9 & 42.7 \\
Orchardgrass silage & 21.5 & - & 36.6 \\
Dry ground corn & 36.2 & - & 11.8 \\
Soybean meal (48\% CP) & 5.81 & 2.50 & 3.39 \\
SoyPLUS ${ }^{1}$ & 1.82 & 3.99 & 3.99 \\
Vitamin-mineral mix ${ }^{2}$ & 3.99 & - & 0.30 \\
Urea & 0.15 & & 1.20 \\
Limestone & 0.60 & 54.5 & 52.3 \\
Chemical composition & & 92.7 & 91.1 \\
DM, \% & 51.6 & 29.2 & 30.2 \\
OM, \% DM & 92.4 & 25.3 & 24.9 \\
NDF, \% DM & 29.1 & 86.8 & 82.3 \\
\% Forage NDF & 24.7 & 14.8 & 8.24 \\
\% NDF from forage & 84.8 & 50.7 & 27.3 \\
iNDF, \% DM & NA & 18.4 & 17.0 \\
iNDF, \% of NDF & NA & 27.3 & 29.6 \\
CP, \% DM & 17.5 & & \\
Starch, \% DM & 33.5 & & \\
\hline
\end{tabular}

${ }^{1}$ West Central Soy Cooperative (Ralston, IA).

${ }^{2}$ Vitamin-mineral mix contained (DM basis) $16.5 \%$ sodium bicarbonate, $14.2 \%$ magnesium sulfate, $7.1 \%$ salt, $5.8 \%$ dicalcium phosphate, $2.4 \%$ trace mineral premix, $0.4 \%$ vitamin $\mathrm{A}, 0.4 \%$ vitamin $\mathrm{D}, 0.2 \%$ vitamin $\mathrm{E}$, and $53.1 \%$ dry ground corn as a carrier.

${ }^{3} \mathrm{iNDF}=$ indigestible NDF.

${ }^{4} \mathrm{NA}=$ no analysis for preliminary diet.

samples were taken for each cow in each period, representing every $3 \mathrm{~h}$ of a 24 -h period to account for diurnal variation. Ruminal contents were evacuated manually through the ruminal cannula $4 \mathrm{~h}$ after feeding at the beginning of $\mathrm{d} 17(1530 \mathrm{~h})$ and $2 \mathrm{~h}$ before feeding at the end of d 18 (0930 h) for each experimental period. Total rumen content mass and volume were determined. To ensure accurate sampling, every tenth handful of digesta $(10 \%)$ was separated for a subsample throughout evacuation. This subsample was squeezed into primarily solid and liquid phases. Both phases were weighed and sampled $(350 \mathrm{~mL})$ for determination of nutrient pool size. All samples were stored at $-20^{\circ} \mathrm{C}$.

\section{Sample Analysis and Calculations}

Analyses of diet ingredients for chemical composition of forages and treatment diets were described in detail by Kammes and Allen (2012). Forage samples were combined to 1 composite sample per forage per period. Particle size distribution was determined using the Penn State Particle Separator containing 2 sieves (19 and $8 \mathrm{~mm}$ ) and a pan (Lammers et al., 1996). In addition, samples were wet sieved manually and sequentially through screens with the following aperture sizes: $19.0,9.50,4.75,2.36,1.18,0.600,0.300,0.150$, 0.075 , and $0.038 \mathrm{~mm}$ (W. S. Tyler Inc., Gastonia, NC). The fraction of DM retained on the screens from wet sieving was used to calculate mean particle size.
Rates of particle size reduction in, and particle passage from, the rumen were determined by using iNDF as a marker (Figure 1). Quadruplicate 25-g TMR and duplicate 25-g orts samples were sieved. Thawed subsamples of ruminal solid and liquid phases from each of 2 rumen evacuations per period were recombined into duplicate 30-g samples based on the original ratio of solid and liquid phases. Duodenal samples were thawed and combined ( 8 per cow per period), separated into liquid and solid phases, and recombined in duplicate 350 -g samples based on the original ratio of solid and liquid phases. Duodenal samples were sieved first to determine threshold size for passage by individually wet sieving samples sequentially through 4.75-, 2.36-, and $0.038-\mathrm{mm}$ screens. Because the $2.36-\mathrm{mm}$ screen was the screen with the largest aperture size that retained duodenal digesta for all cows, $2.36 \mathrm{~mm}$ was selected as the threshold for passage. Particles retained on the 2.36 - and $4.75-\mathrm{mm}$ screens were combined and the resulting fractions were designated as $\geq 2.36$ (large; less likely to escape the rumen) and $<2.36$ (small; more likely to escape the rumen). Orts, TMR, and rumen samples (kept separate for the 2 sampling times) were wet sieved sequentially through the 2.36 - and $0.038-\mathrm{mm}$ screens. Particles retained on each screen were removed, dried at $55^{\circ} \mathrm{C}$ and then weighed. Materials retained on each screen from replicate sievings were combined. The 2 fractions were ground with a Wiley mill (1-mm screen; Arthur H. Thomas Co., Philadelphia, PA) and 
analyzed for DM and iNDF content. Concentrations of NDF were determined according to Mertens (2002). Indigestible NDF was estimated as NDF residue after 240-h in vitro fermentation (Goering and Van Soest, 1970); flasks were reinoculated at $120 \mathrm{~h}$ to ensure a viable microbial population. Ruminal fluid for the in vitro incubations was collected from a nonpregnant dry cow fed dry hay only. The fraction of pdNDF was calculated by difference $(1.00-\mathrm{iNDF})$. Concentrations of all nutrients except DM were expressed as percentages of $\mathrm{DM}$, determined by drying at $105^{\circ} \mathrm{C}$ in a forced-air oven for more than $8 \mathrm{~h}$.

Total intakes, ruminal pool sizes, and duodenal fluxes were discussed in detail by Kammes and Allen (2012). In brief, nutrient intakes were calculated using the composition of feed offered and refused. Ruminal pool sizes $(\mathrm{kg})$ of NDF, iNDF, and pdNDF were determined by multiplying the concentration of each component in rumen samples by the ruminal digesta DM mass $(\mathrm{kg})$. Duodenal fluxes $(\mathrm{kg} / \mathrm{d})$ of NDF and pdNDF were determined using iNDF as a flow marker; iNDF intake $(\mathrm{kg} / \mathrm{d})$ was multiplied by the ratio between the component and iNDF in duodenal digesta.

The reduction rate of iNDF (rate of transfer of iNDF from the large pool to the small pool), passage rates of large iNDF and small iNDF, and relative size threshold for escape from the rumen were calculated as follows:

reduction rate $\left(k_{\mathrm{r}}\right)$ from large pool to small pool:

$$
\begin{gathered}
\text { large iNDF } k_{\mathrm{r}}=\text { [large iNDF } \mathrm{intake}_{\text {Ing }}(\mathrm{kg} / \mathrm{d}) \\
\left.- \text { large } \mathrm{iNDF}_{\text {Duodenal flux }}(\mathrm{kg} / \mathrm{d})\right] / \\
\text { arge iNDF } \\
\text { Rumen pool } \\
(\mathrm{kg}),
\end{gathered}
$$

passage rate $\left(k_{\mathrm{p}}\right)$ :

$$
\begin{gathered}
\text { large iNDF } \mathrm{k}_{\mathrm{p}}=\text { large iNDF } \mathrm{inodenal} \mathrm{flux}_{\text {(kg } / \mathrm{d}) /} \\
\text { large iNDF } \mathrm{inumen} \mathrm{pool}_{\text {Rg }}, \text { and }
\end{gathered}
$$$$
\text { small iNDF } \mathrm{k}_{\mathrm{p}}=\text { small iNDF } \mathrm{inodenal} \mathrm{flux}_{\text {iNDF }}(\mathrm{kg}) / \text { small }
$$$$
\mathrm{iNDF}_{\text {Rumen pool }}(\mathrm{kg}) \text {, }
$$

relative size threshold:

$$
\begin{aligned}
& \text { large } \mathrm{iNDF}_{\text {Duodenal flux }}(\mathrm{kg} / \mathrm{d}) / \\
& \text { total } \mathrm{iNDF}_{\text {Duodenal flux }}(\mathrm{kg} / \mathrm{d}) \text {. }
\end{aligned}
$$

Passage rates and relative size threshold were calculated similarly for pdNDF. Rate of particle size reduction was calculated for iNDF only because it can leave the pool only by breakdown or by passage, whereas
pdNDF can leave the pool by digestion as well as by particle size reduction and passage.

\section{Statistical Analysis}

All data were analyzed by using the fit model procedure of JMP (version 8; SAS Institute Inc., Cary, $\mathrm{NC}$ ). To determine differences between treatments and evaluate interactions of treatment with DMI, where pDMI (calculated as the mean of DMI values on $\mathrm{d} 11$ to 14 of the 14-d preliminary period) was used as the covariate for treatment responses, data were analyzed according to the following model: $\mathrm{Y}_{\mathrm{ijk}}=\mu+\mathrm{C}_{\mathrm{i}}+\mathrm{P}_{\mathrm{j}}+$ $\mathrm{T}_{\mathrm{k}}+\mathrm{PT}_{\mathrm{jk}}+\mathrm{pDMI}+\mathrm{T}_{\mathrm{k}} \mathrm{pDMI}+\mathrm{pDMI}^{2}+\mathrm{T}_{\mathrm{k}} \mathrm{pDMI}^{2}$ $+e_{i j k}$, where $Y_{i j k}$ is the dependent variable, $\mu$ is the overall mean, $\mathrm{C}_{\mathrm{i}}$ is the random effect of cow ( $\mathrm{i}=1$ to 13), $P_{j}$ is the fixed effect of period ( $\mathrm{j}=1$ to 2$), T_{k}$ is the fixed effect of treatment ( $\mathrm{k}=1$ to 2$), \mathrm{PT}_{\mathrm{jk}}$ is the interaction of period and treatment, $\mathrm{pDMI}$ is the linear effect of pDMI, $\mathrm{T}_{\mathrm{k}} \mathrm{pDMI}$ is the interaction of treatment and $\mathrm{pDMI}$ (linear), $\mathrm{pDMI}^{2}$ is the quadratic effect of $\mathrm{pDMI}, \mathrm{T}_{\mathrm{k}} \mathrm{pDMI}{ }^{2}$ is the interaction of treatment and pDMI (quadratic), and $e_{\mathrm{ijk}}$ is the residual error. Statistical significance for $\mathrm{T}_{\mathrm{k}} \mathrm{pDMI}$ and $\mathrm{T}_{\mathrm{k}} \mathrm{pDMI}{ }^{2}$ indicated treatment differences were related to pDMI. Covariate and interaction terms were removed stepwise from the model if $P>0.20$. Treatment effects and their interaction (linear and quadratic relationships) were declared significant at $P \leq 0.05$ and $P \leq 0.10$, respectively. Tendencies for treatment effects and their interactions were declared at $P \leq 0.10$ and $P \leq 0.15$, respectively.

\section{RESULTS AND DISCUSSION}

Results of forage family and its interaction with pDMI did not affect DMI, milk yield, or milk composition (Kammes and Allen, 2012). Although statistically different $(P<0.001)$, the distribution of NDF intake was essentially the same, as approximately $75 \%$ of the NDF consumed was large and $25 \%$ was small for both treatments (Figure 2). As pDMI increased, AL decreased the proportion of NDF consumed as large and increased the proportion consumed as small, whereas both remained relatively constant for OG across the entire range of pDMI (interaction $P=0.03$; Table 4); however, these differences were quite small (10-kg increase in DMI resulted in less than $0.5 \%$ change in distribution) and likely biologically insignificant. The AL diet increased the proportion of NDF consumed as large iNDF and small iNDF and decreased the proportion of NDF consumed as large pdNDF and small pdNDF compared with OG $(P<0.001$; Table 4$)$ because of the differences in chemical composition of forage families, 


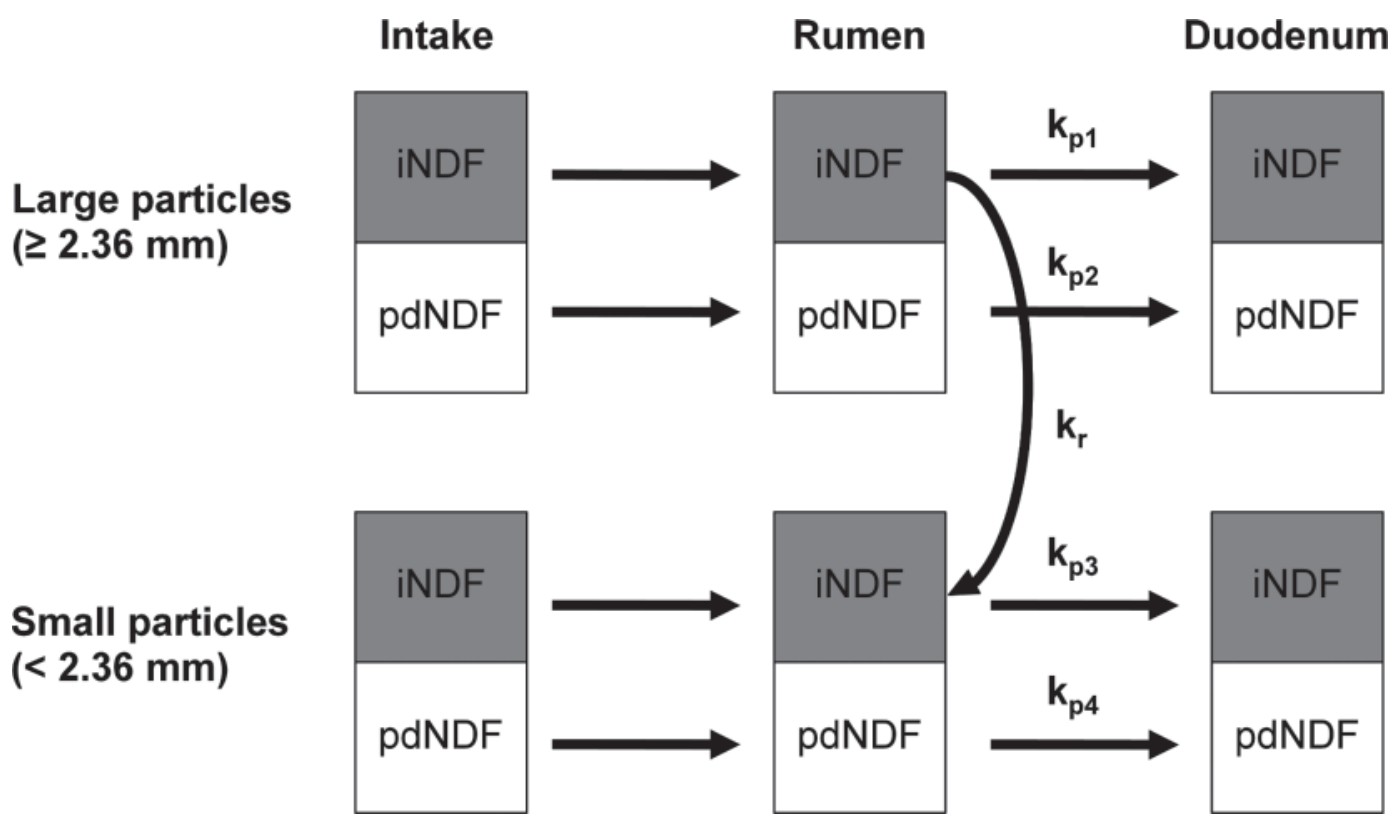

Figure 1. Model of ruminal particle size reduction and passage. Reduction of particle size during eating is included in the rate of particle size reduction $\left(\mathrm{k}_{\mathrm{r}}\right)$. Passage rates $\left(\mathrm{k}_{\mathrm{pi}}\right)$ are calculated for indigestible NDF (iNDF) and potentially digestible NDF (pdNDF); $\mathrm{k}_{\mathrm{r}}$ is calculated for iNDF only. Figure reprinted with permission from Voelker Linton and Allen (2007).

as alfalfa had a higher concentration of iNDF and lower concentration of pdNDF than orchardgrass (Table 2).

The AL diet increased the rate of particle size reduction of iNDF from large to small compared with OG (7.16 vs. $4.67 \% / \mathrm{h}, P<0.001$; Table 5$)$. This is consistent with the greater resistance of grass cell walls to particle breakdown than for alfalfa cell walls because of chemical and structural differences (Wilson and Hatfield, 1997) and contributed to a greater proportion of total NDF in the rumen as small for AL compared with OG $(P<0.001$; Figure 2$)$. The faster reduction rate for AL occurred despite less rumination time spent per unit of forage NDF intake for AL than OG (78.4 vs. $84.7 \mathrm{~min} / \mathrm{kg}$ of forage NDF, $P=0.02$; Kammes and Allen, 2012). These responses indicated that alfalfa NDF was more fragile than orchardgrass NDF. However, 63.1 and $55.8 \%$ of NDF particles in the rumen for $\mathrm{AL}$ and $\mathrm{OG}$, respectively, were below the threshold size for passage (Table 4), which suggested that particle size was not a limiting constraint to passage for either treatment.

Passage rates of large particles from the rumen were less than $1.2 \% / \mathrm{h}$ for iNDF and pdNDF for both treatments (Table 5). Forage family and its interaction with pDMI did not affect ruminal passage rate of large iNDF, but response of ruminal passage rate of large pdNDF was related to pDMI (Table 5). As pDMI increased, AL increased the passage rate of large pdNDF and OG decreased it (interaction $P=0.10$; Figure 3 ).

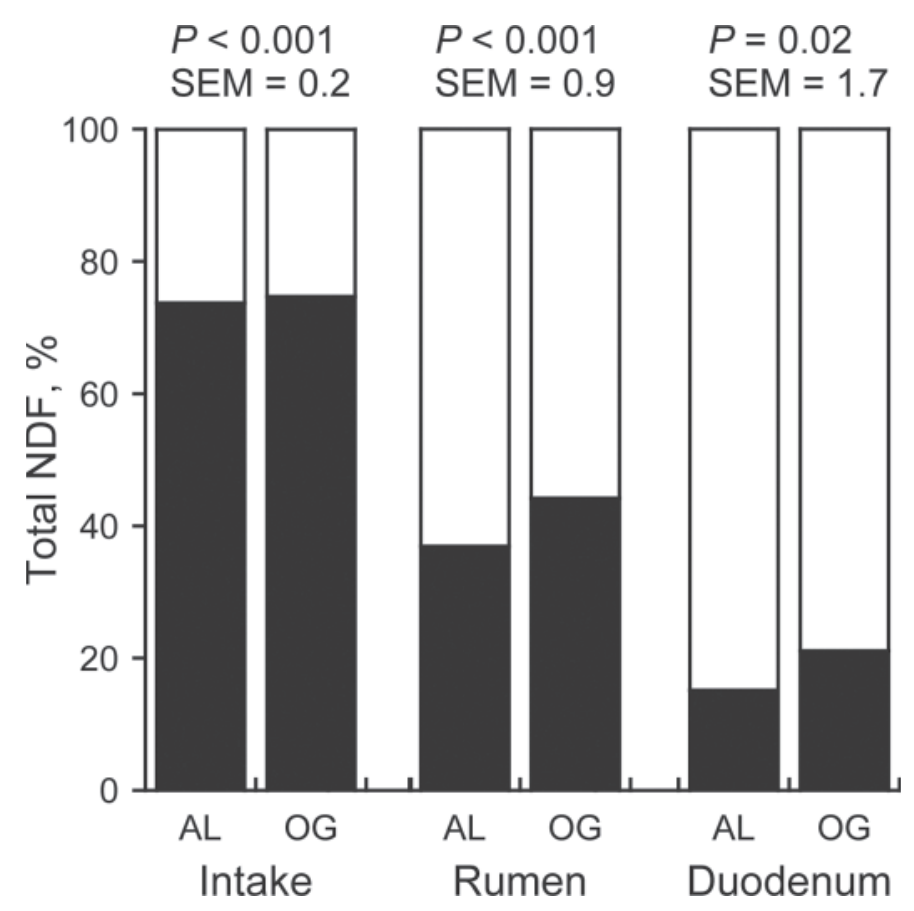

Figure 2. Particle size distribution of NDF in intake, rumen, and duodenum. Proportion of total NDF as large $(\geq 2.36 \mathrm{~mm}$; denoted by black) or small ( $<2.36 \mathrm{~mm}$; denoted by white) particles for cows fed diets containing alfalfa $(\mathrm{AL})$ or orchardgrass $(\mathrm{OG})$ as the sole source of forage. Least squares means and standard error of the mean are shown. $P$-values above each set of columns indicate significance for comparison of AL and OG within NDF large and small particles. 
Table 4. Particle size distribution of intake, rumen pool, and duodenal flux for cows fed treatment diets containing alfalfa (AL) or orchardgrass (OG) silage as the sole source of forage

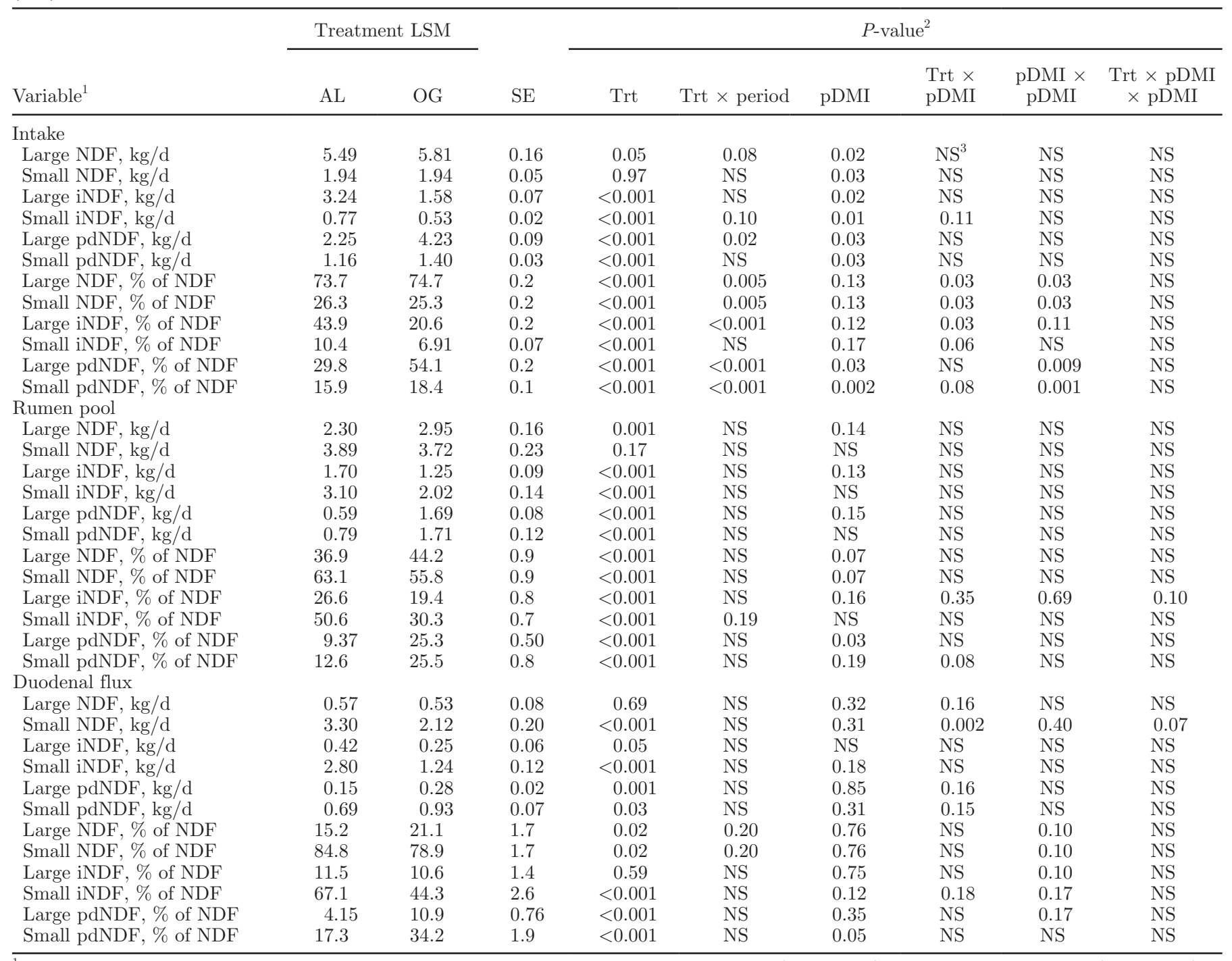

${ }^{1}$ iNDF $=$ indigestible NDF, pdNDF $=$ potentially digestible NDF, Large $=$ large particles $(\geq 2.36 \mathrm{~mm})$, Small $=$ small particles $(<2.36 \mathrm{~mm})$.

${ }^{2} P$-values for treatment $($ Trt), Trt by period interaction (Trt $\times$ period), preliminary DMI $(\mathrm{pDMI})$, Trt by pDMI interaction $($ Trt $\times$ pDMI), quadratic effect of $\mathrm{pDMI}(\mathrm{pDMI} \times \mathrm{pDMI})$, and Trt by quadratic effect of $\mathrm{pDMI}($ Trt $\times \mathrm{pDMI} \times \mathrm{pDMI})$.

${ }^{3}$ Nonsignificant, with $P>0.20$; term was removed from the statistical model.

An increase in passage rate with greater intakes was expected, but the reason for the reduction in passage rate of large pdNDF with increased level of intake for $\mathrm{OG}$ is not known. Responses of passage rates of small particles were not related to $\mathrm{pDMI}$ (Table 5), but AL increased the rates of ruminal passage of small iNDF $(3.85$ vs. $2.66 \% / \mathrm{h}, P<0.001)$ and small pdNDF $(3.80$ vs. $2.50 \% / \mathrm{h}, P=0.002)$ compared with OG. Despite the faster passage rate of small iNDF for AL, approximately $50 \%$ of the particles in the rumen for AL were small iNDF compared with approximately $30 \%$ for OG $(P=0.001$; Table 4$)$, which is because of the greater intake of iNDF for AL than OG. In contrast, approxi- mately $13 \%$ of the particles in the rumen for AL were small pdNDF compared with approximately $26 \%$ for OG $(P=0.001$; Table 4$)$ because of lower pdNDF intake and faster pdNDF digestion rate for AL than OG (Kammes and Allen, 2012). These responses contributed to the higher rumen pool size of iNDF and lower rumen pool sizes of pdNDF, NDF, DM, and digesta wet weight and volume for AL compared with OG, which ultimately resulted in lower rumen fill for AL than OG (Kammes and Allen, 2012).

Passage rates for small pdNDF and small iNDF were similar within forage family (Figure 4). If buoyancy was a factor limiting passage, we would expect pdNDF to 


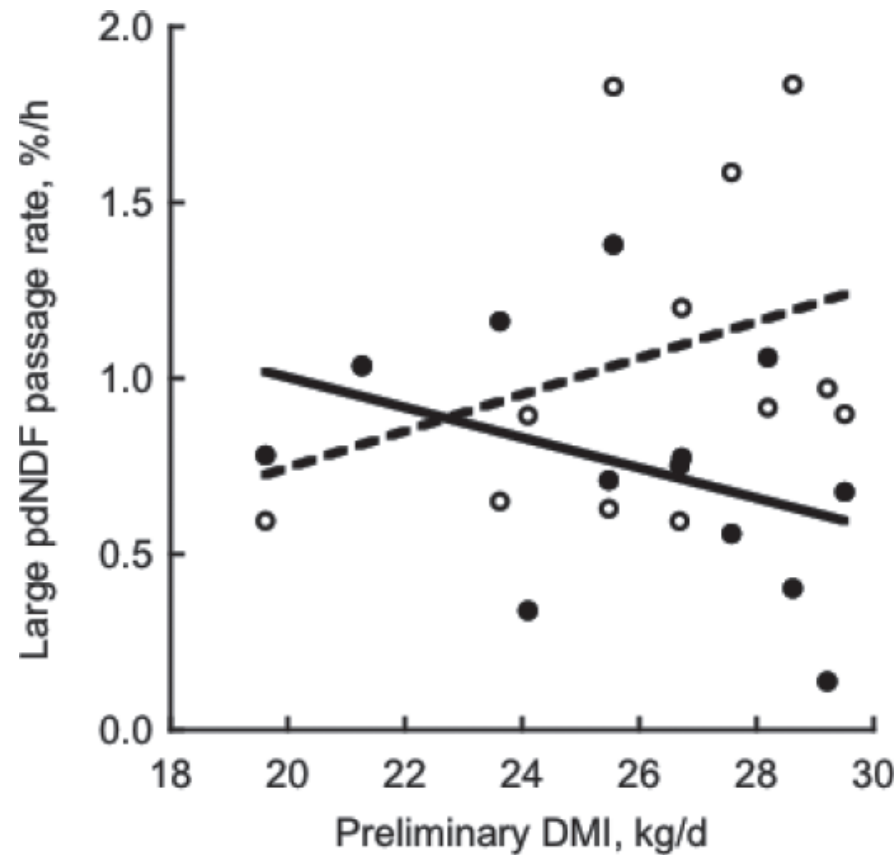

Figure 3. Interaction of alfalfa (open circles, dashed line) and orchardgrass (closed circles, solid line) with preliminary DMI for passage rate of large $(\geq 2.36 \mathrm{~mm})$ potentially digestible NDF (pdNDF) particles (interaction: $P=0.10$; alfalfa: $P=0.24, \mathrm{R}^{2}=0.13$; orchardgrass: $\left.P=0.21, \mathrm{R}^{2}=0.14\right)$. The preliminary DMI on the $\mathrm{x}$-axis are the mean DMI of individual cows during the final $4 \mathrm{~d}$ of the preliminary period when all cows were fed a common diet. The best-fit lines are drawn to demonstrate the significant interaction even if the individual relationships are not significant.

be selectively retained in the rumen and have a slower rate of passage than iNDF. Although both iNDF and pdNDF fractions are contained in the same particle, the probability of particles to pass should increase as the particle increases in iNDF because there is less gas from fermentation of pdNDF associated with the particle, thereby decreasing buoyancy. Although overall passage rate (not fractionated into large and small) of iNDF was greater than pdNDF for $\mathrm{AL}$ and $\mathrm{OG}$ (Kammes and Allen, 2012), the similar passage rates for small iNDF and small pdNDF within forage species suggested buoyancy was likely not a constraint to the passage of small particles from the rumen in the current experiment.

Few studies in the literature report rates of passage of various size particles for iNDF and pdNDF fractions. In a study using the same method as the one used in this experiment, passage rate of iNDF was greater than pdNDF for particles $<2.36 \mathrm{~mm}$ for cows fed low-fiber or high-fiber diets including alfalfa silage and corn silage as forage sources (Voelker Linton and Allen, 2007). Another study reported faster passage rates for iNDF than pdNDF for particles $<2.50 \mathrm{~mm}$ for cows fed a mixed timothy and meadow fescue grass silage, but that study 
used rumen evacuations and fecal output, rather than duodenal flow, to calculate passage rates (Rinne et al., 2002). Results from the 2 studies previously mentioned are in agreement with the above stated logic regarding buoyancy; however, we did not obtain similar findings in this experiment.

The AL diet decreased rumen pool size of large NDF compared with OG (2.30 vs. $2.95 \mathrm{~kg}, P=0.001$; Table 4). The greater pool of large fibrous particles for $\mathrm{OG}$ likely functions to entrap small particles and prevent their sedimentation, which reduces their probability of escape. Results on the distribution of particles within the rumen of cows (Evans et al., 1973) and sheep (Sutherland, 1988) have indicated that the ruminal mat functions very effectively as a retaining mechanism and escape from the mat has been identified as a rate-limiting component of passage of forage particles (Poppi et al., 2001). In addition to the size of particles, shape of particles within the rumen mat is probably important. The cuboidal-shaped fragments of legumes usually pass from the rumen faster than grass particles, which are elongated and needle like (Buxton et al., 1996). The intertwining of long, thin grass particles within the rumen mat might be more efficient at retaining small particles than those of legumes. These factors likely contributed to the slower passage rate of small pdNDF and small iNDF observed for OG.

Rumen pools $(\mathrm{kg})$ of small NDF were similar for $\mathrm{AL}$ and OG $(P=0.17$; Table 4$)$. Despite the faster passage and digestion rates of small particles for AL compared with OG as previously discussed, the pool of small NDF was not smaller for AL than OG because the rate of reduction was also faster such that small particles passed from the rumen or digested in the rumen were replaced by the reduction of large particles into small particles. The composition of the rumen mat and its effect on particle passage is likely a balance between passage, digestion, and reduction rates. If the rates of passage and digestion are slower than the rate of reduction, rumen pools of large particles will decrease and small particles will increase until more large particles are consumed. The accumulation of small particles at the expense of large particles will decrease the ability of the rumen mat to retain small particles.

The AL diet tended to decrease or decreased the proportion of large iNDF (15 vs. $19 \%$; $\times 100$ large iNDF duodenal flux/total iNDF duodenal flux; $P=0.09$ ) and large pdNDF (17 vs. $23 \%$; $\times 100$ large pdNDF duodenal flux/total pdNDF duodenal flux; $P=0.02$ ) particles that escaped the rumen compared with OG (Table 5). This is consistent with the lower proportion of total NDF in duodenal flow as large particles for AL compared with OG $(P=0.02$; Figure 2$)$. The AL diet increased the proportion of small iNDF particles that

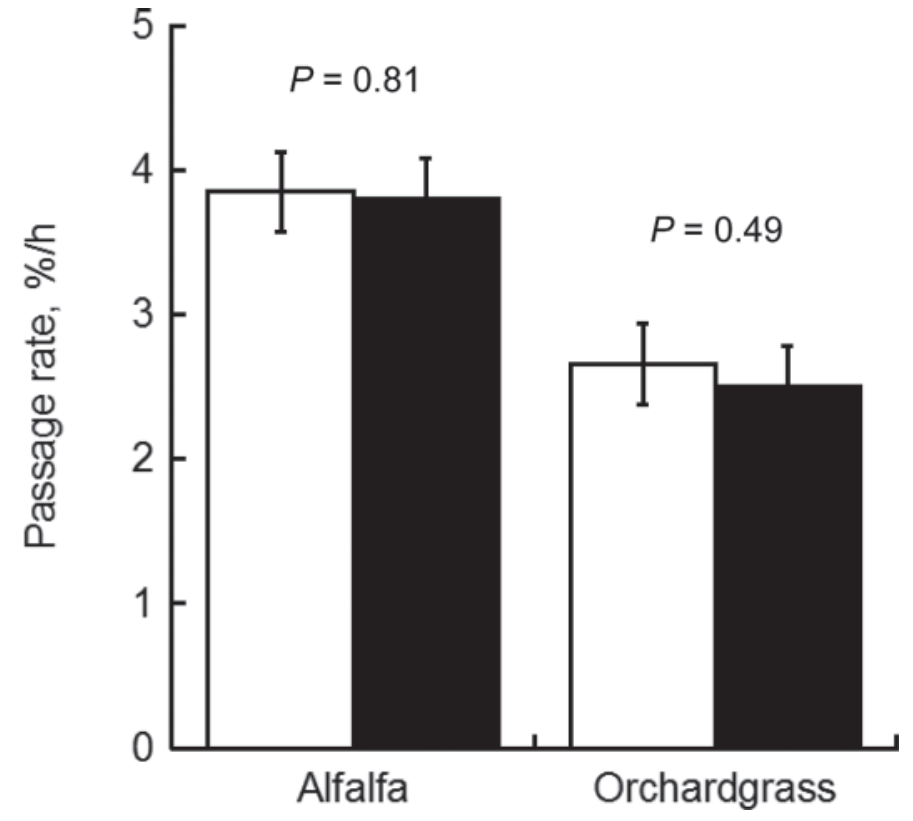

Figure 4. Passage rates of small $(<2.36 \mathrm{~mm})$ indigestible NDF particles (iNDF; white bars) and small potentially digestible NDF particles (pdNDF; black bars) for cows fed diets containing alfalfa or orchardgrass as the sole source of forage. Least squares means are shown and error bars represent standard error of the mean. $P$-values above each set of columns indicate significance for comparison of small iNDF and small pdNDF within alfalfa and orchardgrass based on analysis using a paired $t$-test.

escaped the rumen compared with OG (67.1 vs. $44.3 \%$ of total NDF, $P<0.001$ ), and this fraction comprised the greatest proportion of particles at the duodenum for both treatments (Table 4). However, AL decreased the proportion of small pdNDF particles compared with OG (17.3 vs. $34.2 \%$ of total NDF, $P<0.001$; Table 4 ). Lower intake and greater digestion rate of pdNDF for AL than OG resulted in the reduction in small pdNDF at the duodenum for AL despite the faster passage rate of small pdNDF (Table 5) and lower NDF digestibility $(38.3$ vs. $53.3 \% / \mathrm{h}, 30$-h in vitro fermentation; Table 2$)$ for AL than OG.

\section{CONCLUSIONS}

The AL diet increased rates of reduction of iNDF large to small and passage of small pdNDF and small iNDF compared with OG. The passage rate of particles was not likely limited for either treatment by the rate of reduction or particle size because the proportion of NDF in the rumen below the threshold for passage was greater than $55 \%$. Additionally, it was not likely limited by buoyancy because of similar passage rates for small pdNDF and small iNDF within forage family. The slower passage rate of small pdNDF and small iNDF for OG was likely because of greater entrapment of small NDF 
within the rumen mat by the larger pool of large NDF. Particle size reduction was a prerequisite to ruminal passage but not a limiting constraint in this experiment. When AL or OG was the only source of forage in diets formulated to contain similar concentrations of forage NDF, selective retention of small particles was less for legume than cool-season grass, resulting in lower rumen fill and less effective fiber.

\section{ACKNOWLEDGMENTS}

This project was supported by National Research Initiative Competitive Grant no. 2006-35206-16708 from the US Department of Agriculture National Institute of Food and Agriculture (Washington, DC). The authors thank N. K. Ames (Department of Large Animal Clinical Science, College of Veterinary Medicine, Michigan State University) for performing duodenal and ruminal cannulation surgeries, D. G. Main, R. A. Longuski, Y. Ying (Department of Animal Science, Michigan State University), and R. E. Kreft, and the staff of the Michigan State University Dairy Cattle Teaching and Research Center (East Lansing) for their technical assistance and support, K. C. Main (Department of Animal Science, Michigan State University) for her assistance with wet sieving, Barenbrug USA (Tangent, OR) for their donation of Baridana orchardgrass seed, and West Central Soy Cooperative (Ralston, IA) for donating the SoyPLUS protein supplement.

\section{REFERENCES}

Allen, M. S. 1996. Physical constraints on voluntary intake of forages by ruminants. J. Anim. Sci. 74:3063-3075.

Allen, M. S., and D. R. Mertens. 1988. Evaluating constraints of fiber digestion by rumen microbes. J. Nutr. 118:261-270.

Bayat, A. R., M. Rinne, K. Kuoppala, S. Ahvenjärvi, A. Vanhatalo, and P. Huhtanen. 2010. Ruminal large and small particle kinetics in dairy cows fed red clover and grass silages harvested at two stages of growth. Anim. Feed Sci. Technol. 155:86-98.

Buxton, D. R., D. R. Mertens, and D. S. Fisher. 1996. Forage quality and ruminant utilization. Pages 229-266 in Cool-Season Forage Grasses. L. E. Moser, D. R. Buxton, and M. D. Casler, ed. American Society of Agronomy, Madison, WI.

Evans, E. W., G. R. Pearce, J. Burnett, and S. L. Pillinger. 1973. Changes in some physical characteristics of the digesta in the reticulo-rumen of cows fed once daily. Br. J. Nutr. 29:357-376.
Goering, H. K., and P. J. Van Soest. 1970. Forage Fiber Analysis (Apparatus, Reagents, Procedures, and Some Applications). Agric. Handbook No. 379. US Department of Agriculture-Agricultural Research Service, Washington, DC.

Joy, M. T., E. J. DePeters, J. G. Fadel, and R. A. Zinn. 1997. Effects of corn processing on the site and extent of digestion in lactating cows. J. Dairy Sci. 80:2087-2097.

Jung, H. G., and M. S. Allen. 1995. Characteristics of plant cell walls affecting intake and digestibility of forages by ruminants. J. Anim. Sci. $73: 2774-2790$.

Kammes, K. L., and M. S. Allen. 2012. Nutrient demand interacts with forage family to affect digestion responses in dairy cows. J. Dairy Sci. 95:3269-3287. http://dx.doi.org/10.3168/jds.2011-5021.

Krizsan, S. J., S. Ahvenjärvi, and P. Huhtanen. 2010. A meta-analysis of passage rate estimated by rumen evacuation with cattle and evaluation of passage rate prediction models. J. Dairy Sci. 93:5890-5901.

Lammers, B. P., D. R. Buckmaster, and A. J. Heinrichs. 1996. A simplified method for the analysis of particle sizes of forage and total mixed rations. J. Dairy Sci. 79:922-928.

Mertens, D. R. 2002. Gravimetric determination of amylase-treated neutral detergent fiber in feeds using refluxing in beakers or crucibles: Collaborative study. J. AOAC Int. 85:1217-1240.

Okine, E. K., and G. W. Mathison. 1991. Effects of feed intake on particle distribution, passage of digesta, and extent of digestion in the gastrointestinal tract of cattle. J. Anim. Sci. 69:3435-3445.

Poppi, D. P., W. C. Ellis, J. H. Matis, and C. E. Lascano. 2001. Marker concentration patterns of labeled leaf and stem particles in the rumen of cattle grazing Bermuda grass (Cynodon dactylon) analysed by reference to a raft model. Br. J. Nutr. 85:553-563.

Rinne, M., P. Huhtanen, and S. Jaakkola. 2002. Digestive processes of dairy cows fed silages harvested at four stages of grass maturity. J. Anim. Sci. 80:1986-1998.

Robinson, P. J., S. Tamminga, and A. M. van Vuuren. 1987. Influence of declining level of feed intake and varying proportion of starch in the concentrate on rumen ingesta quantity, composition and kinetics of ingesta turnover in dairy cows. Livest. Prod. Sci. 17:37-62.

Stensig, T., and P. H. Robinson. 1997. Digestion and passage kinetics of forage fiber in dairy cows as affected by fiber-free concentrates in the diet. J. Dairy Sci. 80:1339-1352.

Sutherland, T. M. 1988. Particle separation in the forestomachs of sheep. Pages 43-73 in Aspects of Digestive Physiology in Ruminants. A. Dobson and M. J. Dobson, ed. Cornell Univ. Press, Ithaca, NY.

Voelker Linton, J. A., and M. S. Allen. 2007. Nutrient demand affects ruminal digestion responses to a change in dietary forage concentration. J. Dairy Sci. 90:4770-4779.

Voelker Linton, J. A., and M. S. Allen. 2008. Nutrient demand interacts with forage family to affect intake and digestion responses in dairy cows. J. Dairy Sci. 91:2694-2701.

Wilson, J. R., and R. D. Hatfield. 1997. Structural and chemical changes of cell wall types during stem development: Consequences for fibre degradation by rumen microflora. Aust. J. Agric. Res. $48: 165-180$. 